\title{
Prevalence of diabetes mellitus in the Japanese-Brazilian community of Mombuca, Guatapará, SP
}

\author{
Prevalência do diabetes melito na comunidade \\ nipo-brasileira de Mombuca, Guatapará, SP
}

Regina Célia Garcia de Andrade1,2, Roberta Carvalho de Figueiredo 3 , Maria Cristina Foss-Freitas', Ana Emília Pace ${ }^{4}$, Amaury Lelis Dal Fabbro', Laércio Joel Franco', Milton César Foss' ${ }^{1}$

\begin{abstract}
Objective: To estimate the prevalence of type 2 diabetes mellitus (DM2) and impaired glucose tolerance (IGT) in the Japanese-Brazilian community of Mombuca in relation to risk factors (FR) for diabetes and cardiovascular disease. Subjects and methods: Cross-sectional study with 131 individuals of Japanese ancestry (69\% first generation), aged 20 years or more, submitted to socio-cultural, anthropometric, and biochemistry evaluation. Results: Of the individuals studied ( $n=131$, age $=55.1 \pm 15.9$ years), $58.8 \%$ were women. The prevalence of DM2 and IGT were $13.7 \%$ and $14.5 \%$, respectively. Regarding RF, $76.3 \%$ presented dyslipidemia, $52.7 \%$ abdominal obesity, $48.1 \%$ arterial hypertension, and $42.3 \%$ whole body obesity. Conclusions: The prevalence of DM2, IGT, and RF in this Japanese-Brazilian community was higher than in the adult population of the city of Ribeirão Preto-SP, Brazil, suggesting an increase in risk conditions for these morbidities. Arq Bras Endocrinol Metab. 2011;55(2):127-33
\end{abstract}

\section{Keywords}

Prevalence; diabetes mellitus; impaired glucose tolerance; Japanese Brazilians; cardiovascular risk factors

\section{RESUMO}

Objetivo: Estimar prevalências de diabetes melito tipo 2 (DM2) e tolerância à glicose diminuída (TGD) na comunidade de Mombuca, Guatapará, SP, relacionando-as com fatores de risco (FR) para diabetes e doenças cardiovasculares. Sujeitos e métodos: Estudo transversal com 131 nipo-brasileiros ( $69 \%$ de $1^{\text {a }}$ geração), idade $\geq 20$ anos, ambos os sexos, com avaliação sociocultural, antropométrica e bioquímica. Resultados: Dos 131 participantes (idade média $=55,1 \pm 15,9$ anos), a maioria (58,8\%) era do sexo feminino. As prevalências de DM2 e TGD foram $13,7 \%$ e $14,5 \%$, respectivamente. Em relação aos $\mathrm{FR}, 76,3 \%$ apresentaram dislipidemia, 52,7\%, obesidade abdominal (OA), 48,1\%, hipertensão arterial (HA) e 42,3\%, obesidade geral. Conclusões: As prevalências de DM2, TGD e FR observadas nos nipo-brasileiros foram superiores aos valores da população adulta de Ribeirão Preto, SP, sugerindo acentuação de situações predisponentes dessas morbidades. Arq Bras Endocrinol Metab. 2011;55(2):127-33

\section{Descritores}

Prevalência; diabetes melito; tolerância à glicose diminuída; nipo-brasileiros; fatores de risco
1 Faculdade de Medicina de Ribeirão Preto, Universidade de São Paulo (FMRP-USP), Ribeirão Preto, SP, Brasil

${ }^{2}$ Faculdade de Ciências Farmacêuticas de Ribeirão Preto (FCFRP-USP), Ribeirão Preto, SP, Brasil

${ }^{3}$ Faculdade de Medicina da Universidade Federal de Minas Gerais (UFMG), Belo Horizonte, MG, Brasil ${ }^{4}$ Escola de Enfermagem de Ribeirão Preto, (EERP-USP), Ribeirão Preto, SP, Brasil

Correspondence to: Regina Célia Garcia de Andrade Departamento de Ciências Farmacêuticas, Faculdade de Ciências Farmacêuticas de Ribeirão Preto, USP

Av. do Café s/n. ${ }^{\circ}$ - Campus Universitário

14040-903 - Ribeirão Preto, SP, Brazil

randrade@fcfrp.usp.br

Received on Aug/27/2010 Accepted on Jan/26/2011

\section{INTRODUCTION}

D iabetes mellitus type 2 (DM2), a clinical syndrome of multiple etiology, is becoming increasingly prevalent regardless how developed a country is, representing a public health concern of worldwide dimension. The epidemic of DM2 is widely recognized and is probably related to changes in lifestyle (sedentary behavior and eating habits), obesity and increased life expectancy. The World Health Organization estimates that by 2030 there will be 333 million diabetics in the world, about 11 million of them in Brazil according to estimates of the Ministry of Health (1-3). In the Multicenter Brazilian Study (4), prevalence of DM2 and of 
impaired glucose tolerance (IGT) was 7.6\% and 7.8\%, respectively, in the adult population. A later study conducted in adults in Ribeirão Preto, SP, Brazil, revealed an increase to $12.1 \%$ in the prevalence of DM2 and $7.7 \%$ of IGT (5).

The association of DM2 prevalence with different ethnic groups and its geographic distribution according to lifestyle are fully known. The high prevalence observed among the Pima Indians of Arizona, USA and in Nauru, Oceania, where the highest rate is observed (42\%), demonstrates these ethnic and geographic variations (6). Studies on migrant populations have made important contributions to the understanding of the etiopathogenesis and physiopathology of non-transmissible chronic diseases. The pattern of morbidity-mortality observed in these populations differs from that of the community of origin due to changes in lifestyle and to the incorporation of new cultural and dietary patterns that occured within a short period of time $(7,8)$. This fact was confirmed by Fujimoto and cols. (7) in a study conducted in the population of Japanese origin in Seattle, USA, which revealed a high prevalence of DM2 (16\% among women and 20\% among men) among Japanese Americans compared to those observed in Japanese individuals residing in Tokyo, Japan (4\%-5\%). In Brazil, Japanese immigrants and their descendants represent the largest Japanese community residing outside Japan, with $70 \%$ of them living in the state of São Paulo (SP). A survey carried out in 2000 in the city of Bauru, SP, Brazil, revealed a high prevalence of DM2 $(34.9 \%)$ and a high frequency of blood lipid disorders (84\%), demonstrating the impact of changes in lifestyle, and diet pattern in particular, interacting with a possible genetic susceptibility (9-11). In the countryside of the state of São Paulo close to the city of Ribeirão Preto there is a community of Japanese origin that immigrated more recently (1962) to Brazil located in a semi-rural region and still preserving large part of its traditional life habits. A population of Japanese origin that still maintains its traditional lifestyle may perhaps have a lower prevalence of DM2 and IGT compared to other Brazilian populations of Japanese descendants or descendants of populations from other countries.

Thus, the objective of the present study was to estimate the prevalence of DM2 and IGT in the adult Japanese-Brazilian population of Mombuca, Guatapará, SP, Brazil, and compare it according to the presence of some risk factors (RF) for diabetes and cardiovascular disease.

\section{SUBJECTS AND METHODS}

A cross-sectional study was conducted in the Japanese-Brazilian population of Mombuca, Guatapará, SP, Brazil, during the period from April to December, 2005. A survey was conducted by the Agro-Cultural and Sports Association of Guatapará to identify the population living in the community, according to the inclusion criteria, since the departure of adults seeking work in Japan or in other Brazilian cities is frequent and also of young people who wish to complete their studies outside the community. Inclusion criteria was defined as: being of Japanese descent, age over 20 years and reside in the community during the study. This survey identified 196 individuals over 20 years of age. A total of 131 individuals of Japanese origin (Nikkei) agreed to participate, representing $66.8 \%$ of the Japanese-Brazilian population of the community, aged more than 20 years and of both sexes. On a previously scheduled date, each participant went to the Agro-Cultural and Sports Association of Guatapará to be informed about the study. All participants were interviewed by trained examiners who applied questionnaires concerning sociocultural and health conditions. The subjects were then submitted to medical examination including the measurement of arterial blood pressure (BP), anthropometric parameters (weight, height and abdominal circumference) and laboratory determinations, with the collection of blood samples after overnight fasting conditions and 2 hours after the ingestion of $75 \mathrm{~g}$ of glucose. Laboratory tests were carried out at the facilities of the University Hospital, Faculty of Medicine of Ribeirão Preto, USP. BP was measured with an automatic OMROM instrument; model HEM 741, with a 22 to $32 \mathrm{~cm}$ cuff, adequate for all participants in the study. BP was measured three times on the right arm at 3 to 5 minute intervals, with the participant in the sitting position, with his feet on the floor and with uncrossed legs after a rest of at least 5 minutes. The final BP value considered was the mean of the last two measurements. Individuals with systolic BP $(\mathrm{SBP}) \geq 140 \mathrm{mmHg}$ and diastolic BP $(\mathrm{DBP}) \geq 90 \mathrm{mmHg}$ or taking antihypertensive medication were considered to be hypertensive according to the V Brazilian Guidelines for Hypertension (V Diretrizes Brasileiras de Hipertensão) (12).

Anthropometric measurements were made in duplicate, with the individuals barefoot and wearing light clothing. Weight was measured with a previously calibrated electronic scale $\left(\right.$ Filizola $\left.^{\circledR}\right)$ with $150 \mathrm{~kg}$ capacity and $100 \mathrm{~g}$ precision. Height was measured with an 
anthropometer of $50 \mathrm{~mm}$ precision placed close to the wall on a flat surface, with the individual standing erect, with feet together and heels against the measuring rod. Waist circumference (WC) was measured twice, with a non-elastic metric tape with $50 \mathrm{~mm}$ precision placed half distance from the lower rib margin and the iliac crest, with the mean of the two values being calculated. According to the consensus view of the International Diabetes Federation (13), the cut-off WC values based on gender and ethnic group considered for the Japanese population are $\geq 90$ and $\geq 80 \mathrm{~cm}$ for men and women, respectively (12). Body mass index (BMI) was calculated by dividing the weight in $\mathrm{kg}$ by height in square meters $\left(\mathrm{kg} / \mathrm{m}^{2}\right)$. According to the classification proposed by the International Obesity Task Force (IOTF) for the Asian population, a BMI of 23 to $24.9 \mathrm{~kg} / \mathrm{m}^{2}$ was considered to indicate overweight and a BMI $\geq 25.0$ $\mathrm{kg} / \mathrm{m}^{2}$ was considered to indicate obesity (14).

After a fast of at least 10 hours, $5 \mathrm{~mL}$ of venous blood was collected from each subject in a tube containing sodium fluoride for the determination of glycemia by the enzymatic (hexokinase) method using ultraviolet photometry with a Cobas Mira Plus instrument and glucose HK kits. Fingertip glycemia was then measured and when a value of less than $200 \mathrm{mg} / \mathrm{dL}$ was obtained subjects were submitted to an oral glucose tolerance test (OGTT) after the ingestion of $75 \mathrm{~g}$ of anhydrous glucose. Subjects with a previous diagnosis of DM2 were not submitted to the OGTT. According to the criteria established by the World Health Organization (15), individuals with a fasting glycemia $\geq 126 \mathrm{mg} /$ $\mathrm{dL}$, or with glycemia $\geq 200 \mathrm{mg} / \mathrm{dL}$ two hours after glucose ingestion or patients under treatment for diabetes were considered to be diabetic. Impaired fasting glycemia (IFG) was diagnosed in individuals with fasting glycemia values of 110 to $125 \mathrm{mg} / \mathrm{dL}$ and lower than $140 \mathrm{mg} / \mathrm{dL}$ during the second hour after $75 \mathrm{~g}$ glucose, and impaired glucose tolerance was diagnosed in individuals with fasting glycemia $<126 \mathrm{mg} / \mathrm{dL}$ and glycemia values of 140 to $199 \mathrm{mg} / \mathrm{dL}$ during the second hour after $75 \mathrm{~g}$ glucose test. No subject with IFG was detected and therefore in the present study impaired glucose homeostasis (IGH) only reflected IGT and DM2 conditions. For the determination of lipid profile, venous blood samples were collected into dry tubes and analyzed by the automatic spectrophotometry method using an Integra 400 apparatus. Total cholesterol (TC) values were considered to be altered when $\geq 200 \mathrm{mg} /$ dL. For HDL-cholesterol (HDL-C), values $<40 \mathrm{mg} / \mathrm{dL}$ and $<50 \mathrm{mg} / \mathrm{dL}$ were considered altered for men and women, respectively. LDL-cholesterol (LDL-C) values were calculated according to the Friedwald formula except when triglyceride (TG) values were $\geq 400 \mathrm{mg}$ / $\mathrm{dL}$. LDL-C values $\geq 130 \mathrm{mg} / \mathrm{dL}$ and TG values $\geq 150$ $\mathrm{mg} / \mathrm{dL}$ were considered altered based on the National Cholesterol Education Program. Individuals with at least one altered lipid fraction or taking hypolipemic medication were considered dyslipidemic (16).

Continuous variables were compared by the Student $t$-test or by ANOVA. The association between explicative variables (some risk factors) and the response variable (presence of IGH) was measured by the prevalence ratio (PR) and its respective 95\% confidence intervals (95\% CI) using the Epidat 3.1 - Katz software (17). Statistical significance of the associations was evaluated by the Pearson chi-squared $\left(X^{2}\right)$ test or by the Fisher exact test when the number of observations was less than five. The level of significance was set at $5 \%$ in all analyses. Data are reported as means and standard deviations, $95 \% \mathrm{CI}$ or percentage.

The study protocol was approved by the Research Ethics Committee of the Teaching Health Center, Faculty of Medicine of Ribeirão Preto, SP, (no. 104/03) and all subjects gave written informed consent to participate.

\section{RESULTS}

Most of the 131 individuals interviewed were females (58.8\%). Age ranged from 21 to 89 years (mean: 56.7 \pm 15.9 years), $57.8 \pm 15.9$ years in the women's group and $55.1 \pm 15.9$ years in the men's group (Table 1). There was a predominance of first-generation (Issei) individuals $(68.7 \%)$ over second-generation (Nisei) individuals (31.3\%). Mean age of Issei and Nisei subjects was $62.6 \pm 12.5$ and $43.8 \pm 15.1$ years, respectively. Table 1 also shows the mean and standard deviations of weight, height, BMI and WC, in addition to fasting venous plasma glycemia (VPG-f) and VPG in the $2^{\text {nd }}$ hour after glucose overload (VPG-2 $\left.{ }^{\text {nd }} h\right)$. Mean BMI values for both the general population and the population stratified by sex were higher than the cut-off point $\left(\geq 23 \mathrm{~kg} / \mathrm{m}^{2}\right)$ suggested for overweight/obesity for the Asian population (14). Mean weight, height, and WC values were significantly higher for men than for women. Mean WC value was higher than the cut-off point $(\geq 80 \mathrm{~cm})$ proposed by the IDF for the Japanese population (13). Mean VPG-2 ${ }^{\text {nd }} \mathrm{h}$ was higher among women, but the difference between genders was nonsignificant. 
Table 1. Sociodemographic and anthropometric characteristics of the Japanese-Brazilian population of Mombuca, Guatapará, SP, according to sex

\begin{tabular}{|c|c|c|c|c|c|c|c|}
\hline \multirow[t]{2}{*}{ Variables } & \multicolumn{2}{|c|}{$\begin{array}{c}\text { Total } \\
(\mathrm{N}=131)\end{array}$} & \multicolumn{2}{|c|}{$\begin{array}{c}\text { Men } \\
(\mathrm{N}=54)\end{array}$} & \multicolumn{2}{|c|}{$\begin{array}{l}\text { Women } \\
(\mathrm{N}=77)\end{array}$} & \multirow[t]{2}{*}{ p-value ${ }^{a}$} \\
\hline & $\mathbf{N}$ & $\%$ & $\mathbf{N}$ & $\%$ & $\mathbf{N}$ & $\%$ & \\
\hline $\begin{array}{l}\text { Generation } \\
\text { Issei } \\
\text { Nisei }\end{array}$ & $\begin{array}{l}90 \\
41\end{array}$ & $\begin{array}{l}68.7 \\
31.3\end{array}$ & $\begin{array}{l}38 \\
16\end{array}$ & $\begin{array}{l}70.4 \\
29.6\end{array}$ & $\begin{array}{l}52 \\
25\end{array}$ & $\begin{array}{l}67.5 \\
32.5\end{array}$ & 0.730 \\
\hline $\begin{array}{l}\text { Age (years) } \\
20-39 \\
40-59 \\
>60\end{array}$ & $\begin{array}{l}18 \\
64 \\
49\end{array}$ & $\begin{array}{l}13.7 \\
48.9 \\
37.4\end{array}$ & $\begin{array}{l}08 \\
27 \\
19\end{array}$ & $\begin{array}{l}14.8 \\
50.0 \\
35.2\end{array}$ & $\begin{array}{l}10 \\
37 \\
30\end{array}$ & $\begin{array}{l}13.0 \\
48.0 \\
39.0\end{array}$ & 0.911 \\
\hline & \multicolumn{6}{|c|}{ Mean \pm Standard deviation } & $\mathrm{p}$-value $\mathrm{e}^{\mathrm{b}}$ \\
\hline Age (years) & 56.7 & \pm 15.9 & 55.1 & \pm 15.9 & 57.8 & \pm 15.9 & 0.317 \\
\hline Weight (kg) & 61.7 & \pm 14.3 & 70.6 & \pm 14.5 & 55.2 & \pm 10.2 & $<0.001^{*}$ \\
\hline Height (m) & & \pm 0.1 & & \pm 0.1 & & \pm 0.1 & $<0.001^{*}$ \\
\hline $\begin{array}{l}\text { Body mass index - } \\
\text { BMI }\left(\mathrm{kg} / \mathrm{m}^{2}\right)\end{array}$ & & \pm 4.0 & 25.4 & \pm 4.2 & & \pm 3.9 & $0.027^{\star}$ \\
\hline $\begin{array}{l}\text { Waist circumference } \\
\text { - WC }(\mathrm{cm})\end{array}$ & 84.9 & \pm 10.6 & 88.6 & \pm 10.1 & 83.1 & \pm 10.7 & $<0.001^{*}$ \\
\hline $\begin{array}{l}\text { Fasting plasma } \\
\text { venous glycemia } \\
\text { (PVG-F) (mg/dL) }\end{array}$ & 92.6 & \pm 16.3 & 93.7 & \pm 14.6 & 91.5 & \pm 17.5 & 0.36 \\
\hline $\begin{array}{l}\text { Plasma venous } \\
\text { glycemia } 2^{\text {nd }} \text { (PVG } \\
\left.-2^{\text {nd }} \mathrm{h}\right)(\mathrm{mg} / \mathrm{dL})\end{array}$ & 121. & \pm 56.3 & 112 & \pm 46.9 & 128 & \pm 61.8 & 0.09 \\
\hline
\end{tabular}

Issei and Nisei: first and second generation, respectively; ${ }^{~} \mathrm{p}$-value, Fisher's exact test (men $v$. women); ${ }^{b} p$-value, Student t-test (men vs. women), ${ }^{\star}$ statistical significance $(p<0.05)$

The prevalence of IGT and DM2 in the total population was $14.5 \%$ (95\% CI: 9.0-21.7) and $13.7 \%(95 \%$ CI: 8.4-20.8), respectively (Table 2). Comparison between generations revealed that the prevalence of IGH was higher among Issei (32.2\%) than among Nisei $(19.5 \%)$, although the association was not statistically significant $(\mathrm{PR}=1.65$ and 95\% CI: $0.83-3.29 \cdot \mathrm{p}=$ $0.134)$. Women had a higher prevalence of both IGT (20.8 vs. 5.6\%, 95\% CI: 0,027-0.277) and DM2 (15.6 vs. $11.1 \%, 95 \%$ CI: $-0.08-0.177)$ than men did. The prevalence of DM2 compared to IGT (5.6\%) was higher among men (11.1\%). Different behavior was observed among women, who showed predominance of IGT $(20.8 \%)$ compared to DM2 (15.6\%), with the difference between genders being significant $(\mathrm{p}<0.05)$.

When the prevalence of IGT and DM2 was compared in the sample stratified by age range (Figure 1), a progressive increase was observed with age. There was a 4 fold increase in the prevalence of diabetes when the 20 to 39 year age range $(5.6 \%)$ was compared to individuals older than 60 years $(22.4 \%)$, although the difference was nonsignificant $(\mathrm{p}=0.08)$. Prevalence of IGT also increased with the age of participants but was quite elevated even in the younger age range (20-39 years).
Table 2. Prevalence of IGT and DM2 by point and by $95 \%$ confidence interval for the Japanese-Brazilian population of Mombuca, Guatapará, SP, according to sex

\begin{tabular}{|c|c|c|c|c|}
\hline Condition & $\begin{array}{c}\text { Total } \\
\text { (N = 131) } \\
\% \\
95 \% \mathrm{Cl}\end{array}$ & $\begin{array}{c}\text { Men } \\
(\mathrm{N}=54) \\
\% \\
95 \% \mathrm{Cl}\end{array}$ & $\begin{array}{c}\text { Women } \\
\text { (N = 77) } \\
\% \\
95 \% \mathrm{Cl}\end{array}$ & p-value \\
\hline $\begin{array}{l}\text { Normoglycemic } \\
(\mathrm{N}=94)\end{array}$ & $\begin{array}{c}71.8 \\
(63.2-79.3)\end{array}$ & $\begin{array}{c}83.3 \\
(70.7-92.1)\end{array}$ & $\begin{array}{c}63.6 \\
(51.9-74.3)\end{array}$ & \multirow{3}{*}{$0.022^{\star}$} \\
\hline $\begin{array}{l}\text { IGT } \\
\qquad(\mathrm{N}=19)\end{array}$ & $\begin{array}{c}14.5 \\
(9.0-21.7)\end{array}$ & $\begin{array}{c}5.6 \\
(1.2-15.4)\end{array}$ & $\begin{array}{c}20.8 \\
(12.4-31.5)\end{array}$ & \\
\hline $\begin{array}{l}\text { DM2 } \\
\qquad(\mathrm{N}=18)\end{array}$ & $\begin{array}{c}13.7 \\
(8.4-20.8)\end{array}$ & $\begin{array}{c}11.1 \\
(4.2-22.6)\end{array}$ & $\begin{array}{c}15.6 \\
(8.3-25.6)\end{array}$ & \\
\hline
\end{tabular}

$95 \% \mathrm{Cl}=95 \%$ confidence interval; IGT = impaired glucose tolerance; DM2 = diabetes mellitus type 2; ${ }^{*} p$-value, Fisher's exact test; * statistical significance $(p<0.05)$.

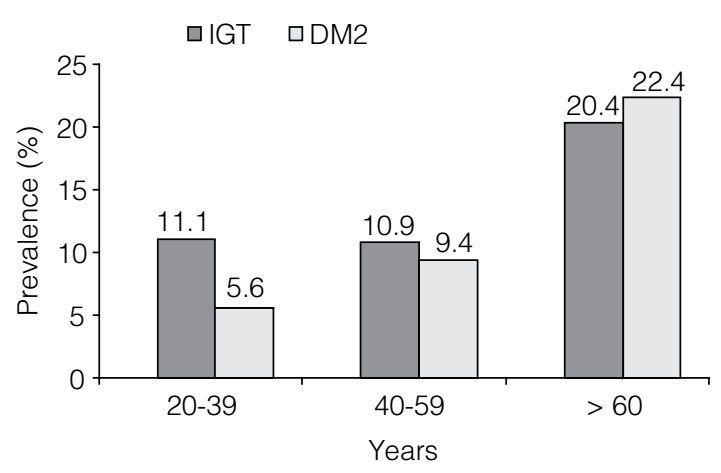

Figure 1. Prevalence of IGT and DM2 in the Japanese-Brazilian population of Mombuca, Guatapará, SP, according to different age ranges $(p=0.08)$.

Prevalence of the main RF detected in the study population was $21.5 \%$ for overweight, $42.3 \%$ for obesity, $52.7 \%$ for abdominal obesity, $48.1 \%$ for arterial hypertension, and $76.3 \%$ for dyslipidemia.

Both prevalence and the prevalence ratio of RF according to the presence of IGT and DM2 in the Japanese-Brazilian population are presented in table 3 . The prevalence of arterial hypertension was two times higher in individuals with IGT (PR $=1.98$ and 95\%CI: $1.36-2.88)$ and $\mathrm{DM} 2(\mathrm{PR}=2.10$ and $95 \% \mathrm{CI}: 1.46-$ 2.99 ) compared to normoglycemic individuals. A positive association was observed between abdominal obesity and IGT (PR = 1.59 and 95\%CI: 1.13-2.25) and DM2 (PR $=1.40$ and 95\%CI: 0.92-2.12) compared to normoglycemic individuals, although a significant association was observed only with IGT.

\section{DISCUSSION}

The Japanese-Brazilian community of Mombuca was established in the 1960's at the former Guatapará 
Table 3. Prevalence and prevalence ratios of risk factor for the Japanese-Brazilian population of Mombuca, Guatapará, SP, according to glycemic condition (IGT and DM2)

\begin{tabular}{|c|c|c|c|c|c|c|c|c|}
\hline & \multicolumn{2}{|c|}{ Normal } & \multicolumn{2}{|c|}{ IGT } & \multirow{2}{*}{$\begin{array}{c}\text { PR } \\
95 \% \text { Cl }\end{array}$} & \multicolumn{2}{|c|}{ DM2 } & \multirow{2}{*}{$\begin{array}{c}\text { PR } \\
95 \% \mathrm{CI}\end{array}$} \\
\hline & $\mathbf{N}$ & $\%$ & $\mathbf{N}$ & $\%$ & & $\mathbf{N}$ & $\%$ & \\
\hline \multicolumn{9}{|l|}{ Dyslipidemia } \\
\hline Yes & 69 & 73.4 & 15 & 78.9 & 1.07 & 16 & 88.9 & 1.21 \\
\hline No & 25 & 26.6 & 4 & 21.0 & $(0.82-1.40)$ & 2 & 11.1 & $(0.99-1.48)$ \\
\hline \multicolumn{9}{|l|}{ Excess weight } \\
\hline Yes $\left(B M l \geq 23 \mathrm{~kg} / \mathrm{m}^{2}\right)$ & 58 & 61.7 & 13 & 68.4 & 1.10 & 11 & 64.7 & 1.05 \\
\hline No $(B M I<23$ kg/m²) & 36 & 38.3 & 6 & 31.6 & $(0.78-1.56)$ & 6 & 35.3 & $(0.71-1.54)$ \\
\hline \multicolumn{9}{|l|}{ Arterial hypertension } \\
\hline Yes & 35 & 37.2 & 14 & 73.7 & 1.98 & 14 & 77.8 & 2.10 \\
\hline No & 59 & 62.8 & 5 & 26.3 & $(1.36-2.88)^{*}$ & 4 & 22.2 & $(1.46-2.99)^{\star}$ \\
\hline \multicolumn{9}{|l|}{ Abdominal obesity } \\
\hline Yes & 43 & 46.2 & 14 & 73.7 & 1.59 & 11 & 64.7 & 1.40 \\
\hline No & 50 & 53.8 & 5 & 26.3 & $(1.13-2.25)^{*}$ & 6 & 35.3 & $(0.92-2.12)$ \\
\hline
\end{tabular}

IGT: impaired glucose tolerance; DM2: diabetes mellitus type 2; 95\% Cl: 95\% confidence interval; PR: prevalence ratio; BMI: body mass index; p-value, Fisher's exact test; ${ }^{\star}$ statistical significance $(p<0.05)$.

Farm, located in the region of Ribeirão Preto, SP, with the arrival of the first immigrants in 1962. Predominance of Issei individuals and the mean age of the total population agree with the recent composition of the community. The Japanese-Brazilians of Mombuca still cultivate many life habits from their origins, including the Japanese language and customs. Throughout a series of interviews, the help of interpreters was required to overcome the language barrier.

Prevalence of IGH, considering individuals with DM2 or IGT, detected in the total population studied here was high $(28.2 \%)$ involving more than one quarter of the participating population. The observed prevalence of DM2 (13.7\%) was higher than the values detected in the Multicenter Study of the Prevalence of Diabetes Mellitus in Brazil (4), 7.6\% for the national mean and $9.6 \%$ for the city of São Paulo $(9.6 \%)$, and was comparable to the $12.1 \%$ prevalence detected in the adult population aged 30 to 69 years in a study conducted in Ribeirão Preto, SP, 1997 (5). The observed prevalence of DM was of slightly lower values compared to data obtained in recent studies in Ribeirão Preto-SP $(15.02 \%)$ and region $(13.5 \%)(18,19)$. However, it differed from the $34.9 \%$ value observed in the second survey performed in 2000 in the Japanese-Brazilian population of Bauru, SP (9-11). The difference detected in diabetes prevalence between the two Japanese-Brazilian populations may be explained in part by the higher degree of physical activity due to farming work performed by the Mombuca community (20), by the shorter time of exposure to the Brazilian customs and the consequent maintenance of an important part of the habits from the country of origin. Other studies have also shown that Japanese descendants living outside Japan are more susceptible to diabetes, dyslipidemia and cardiovascular diseases. Hara and cols. (8) observed that the prevalence of DM2 among Japanese immigrants living in Hawaii and in Los Angeles was three times higher than that observed among the inhabitants of Hiroshima, Japan. Regarding IGT prevalence, the present result (14.5\%) was equal to that detected in the first survey conducted in Bauru, SP (14.5\%) in 1993 and was much lower than that detected in the second survey $(23.2 \%)$ in 2000 , but almost double the $7.7 \%$ value detected in Ribeirão Preto, SP (5, 9-11). Our results on IGT corresponds to three times that of the findings of recent studies Moraes and cols. (18) in Ribeirão Preto, SP (5.53\%) and Bosi and cols. (19) in São Carlos, SP (5\%). Considering that individuals with IGT are a at higher risk to progress to diabetes, this finding suggests that the prevalence of diabetes in the Japanese-Brazilian population of Mombuca will increase considerably over the next few years if the current lifestyle conditions should persist.

The gender differences pointed out in the present study regarding prevalence of glycemic homeostasis abnormalities were not detected in the National and Ribeirão Preto, SP, studies $(4,5)$. However, similar variations were detected by Fujimoto and cols. $(7,21)$ among second-generation Japanese-Americans (Nisei) aged 45 to 74 years in Seattle, USA, with a $20 \%$ and $16 \%$ prevalence of DM2 and a $36 \%$ and $40 \%$ prevalence of IGT among men and women, respectively. In the present study, as also in other surveys, a direct relation 
was detected between an increased number of individuals with some alteration of glycemic homeostasis (IGT and DM2) and increasing age, although the difference between prevalence of diabetes in the 20-39 year $(5.6 \%)$ and the over 60 year $(22.4 \%)$ groups was not statistically significant, probably because of the small number of participants in each group.

Prevalence of general obesity (42.3\%) observed and of arterial hypertension (48.1\%) was higher than that detected in Ribeirão Preto $(22.1 \%$ and $40.5 \%$, respectively) in 1997 (22).

DM2 is frequently associated with different risk factors including arterial hypertension, abdominal obesity, and dyslipidemia (23). A 1993 study conducted in the adult Japanese-Brazilian population of Bauru, SP, also showed a high prevalence of abdominal obesity, arterial hypertension, and dyslipidemia $(24,25)$. The Multiple Risk Factor Intervention Trial (MRFIT) and the United Kingdom Prospective Diabetes Study (UKPDS) confirmed the impact of the classic risk factors for cardiovascular diseases on the mortality of diabetic individuals compared to non-diabetic subjects $(26,27)$.

The study of Ni-Hon-San suggests that Japanese people and their descendants present higher rates of coronary disease when exposed to Western culture according to the findings of these authors which show that the prevalence of coronary disease is lower in the Japanese population residing in Japan is intermediate in the population living in Hawaii, and higher in the Japanese population living in California (28).

Two of the limitations of the present study were the cross-sectional design that only permitted the analysis of data association but not to infer cause-effect relations and the lack of detection of significance between some associations of variables of interest and outcome, a fact that can probably be explained by the small number of individuals studied.

The higher prevalence of IGT among females suggests that the risk of progression to diabetes is higher for this gender for whom primary prevention measures should be a priority. The high prevalence of dyslipidemia, abdominal obesity, and arterial hypertension suggest that the Japanese-Brazilian population of Mombu$\mathrm{ca}$ is at high risk of developing cardiovascular diseases.

Acknowledgments: We are grateful to Fundação de Apoio ao Ensino, Pesquisa e Assistência do Hospital das Clínicas da Faculdade de Medicina de Ribeirão Preto da Universidade de São Paulo for financial support. We also wish to thank Associação Agro-Cultural e Esportiva de Guatapará, for support and the Japanese-Brazilian population of Mombuca for participating in the study.
Disclosure: no potential conflict of interest relevant to this article was reported.

\section{REFERENCES}

1. King H, Aubert RE, Herman WH. Global burden of diabetes, 19952025: prevalence, numerical estimates, and projections. Diabetes Care. 1998;21:1414-31.

2. Wild S, Roglic G, Green A, Sicree R, King H. Global prevalence of diabetes. Estimates for the year 2000 and projections for 2030. Diabetes Care. 2004;27:1047-53.

3. Brasil. Ministério da Saúde. Secretaria de Atenção à Saúde. Departamento de Atenção Básica. Diabetes Mellitus/Ministério da Saúde, Secretaria de Atenção à Saúde, Departamento de Atenção Básica. Brasília: Ministério da Saúde 2006. 64p. il. (Cadernos de Atenção Básica, n. 16) (Série A Normas e Manuais Técnicos).

4. Malerbi DA, Franco LJ. Multicenter study of the prevalence of diabetes mellitus and impaired glucose tolerance in urban Brazilian population aged 30-69 years. Diabetes Care. 1992;15:1509-16.

5. Torquato MTCG, Montenegro Jr RM, Viana LA, Souza RAG, Lanna CMM, Lucas JCB, et al. Prevalence of diabetes mellitus and impaired glucose tolerance in the urban population aged 30-69 years in Ribeirão Preto (São Paulo), Brazil. São Paulo Med J. 2003;21:224-30.

6. Franco LJ. Um problema de Saúde Pública - Epidemiologia. In: Oliveira JEP, Milech A, eds. Diabetes mellitus - Clínica, diagnóstico e tratamento multidisciplinar. São Paulo: Atheneu; 2004. p. 19-32.

7. Fujimoto WY, Leonetti DL, Kinyoun JL, Newell-Morris LL, Shuman WP, Stolov WC, et al. Prevalence of diabetes mellitus and impaired glucose tolerance among second generation Japanese American men. Diabetes. 1987;36:721-9.

8. Hara H, Egusa G, Yamakido M, Kawate R. The high prevalence of diabetes mellitus and hyperinsulinemia among the Japanese-Americans living in Hawaii and Los Angeles. Diabetes Res Clin Pract. 1994;24(suppl.):37-S42.

9. Franco LJ, Gimeno SGA, Ferreira SRG, lunes M. Incremento na mortalidade associada à presença de diabetes mellitus em nipo-brasileiros. Rev Saude Publica. 1998;32:118-24.

10. Gimeno SGA, Ferreira SRG, Franco LJ, Hirai AT, Matsumura RS, Moisés RS. Prevalence and 7-year incidence of Type II diabetes mellitus in a Japanese-Brazilian population: an alarming public health problem. Diabetologia. 2002;45:1635-38.

11. Grupo de Estudos de Diabetes na Comunidade Nipo-brasileira (JBDSG). Diabetes mellitus e doenças associadas em nipo-brasileiros, São Paulo. São Paulo: Green Forest do Brasil Editora; 2004.

12. V Diretrizes Brasileiras de Hipertensão Arterial (2006). Arq Bras Cardiol. 2007;89(3):e24-79.

13. Alberti KGMM, Zimmet $P$, Shaw J. International Diabetes Federation: a consensus on Type 2 diabetes prevention. Diabet Med. 2007;24:51-63.

14. Weisell RC. Body mass index as an indicator of obesity. Asia Pac J Clin Nutr. 2002;11(suppl.):S681-4.

15. World Health Organization. Definition, diagnosis and classification of diabetes mellitus and its complications. Report of a WHO consultation. Geneva:WHO; 1999. 59 p (WHO/NCD/NCS/99-2).

16. Expert Panel on Detection, Evaluation, and Treatment of High Blood Cholesterol in Adults (Adult Treatment Panel III). Executive summary of the third report of the National Cholesterol Education Program (NCEP). JAMA. 2001;285:2486-97.

17. Epidat. Programa para análise epidemiológica de dados tabulados (versão 3.1). Organização Panamericana da Saúde e Xunta de Galicia; Jan 2006. 
18. Moraes SA, Freitas ICM, Gimeno SGA, Mondini L. Prevalência de diabetes mellitus e identificação de fatores associados em adultos residentes em área urbana de Ribeirão Preto, São Paulo, Brasil, 2006: Projeto OBEDIARP. Cad Saúde Pública. 2010;26(5):929-41.

19. Bosi PL, Carvalho AM, Contrera D, Casale G, Pereira MA, Diogo $\mathrm{TM}$, et al. Prevalência de diabetes melito e tolerância à glicose diminuída na população urbana de 30 a 79 anos da cidade de São Carlos, São Paulo. Arq Bras Endocrinol Metab. 2009;53(6):726-32.

20. Franco LJ, Souza S, Sartorelli D, Figueiredo RC, Pace A, Foss-Freitas MC, et al. Urban - rural differences in the prevalence of abnormalities in glucose tolerance among Japanese - Brazilians - is the diet or lack of physical activity the reason? Diabetic Medicine. 2006;23(suppl.4):171-2.

21. Fujimoto WY, Bergstrom RW, Boyko EJ, Kinyon JL, Leonetti DL, Newell-Morris $\mathrm{LI}$, et al. Diabetes and diabetes risk factors in second-and third-generation Japanese Americans in Seattle, Washington. Diabetes Res Clin Pract. 1994;24(suppl.):S43-52.

22. Ribeirão Preto. Secretaria Municipal da Saúde. Protocolo de Atendimento em Diabetes e Hipertensão 2006 [cited Oct 29, 2010]. 90 p. Available in: http://www.ribeiraopreto.sp.gov.br / ssaude/programas/cronico/prot-hipertensao.pdf.
23. Schaan BDA, Harzheim E, Gus I. Perfil de risco cardíaco no diabetes mellitus e na glicemia de jejum alterada. Rev Saude Publica. 2004;38(4):529-36.

24. Ferreira SRG, lunes M, Franco LJ, lochida AH, Vivolo MA. Disturbances of glucose and lipid metabolism in first and second generation Japanese - Brazilians. Diabetes Res Clin Pract. 1996;34(suppl.):S59-63.

25. Freire RD, Cardoso MAC, Gimeno SGA, Ferreira SRG. Dietary fat is associated with metabolic syndrome in Japanese Brazilians. Diabetes Care. 2005;28(7):1779-85.

26. Stamler J, Vaccaro O, Neaton ID, Wentworth D. Diabetes, other risk factors, and $12 \mathrm{yr}$ cardiovascular mortality for men screened in the Multiple Risk Factor Intervention Trial. Diabetes Care. 1993;16(2):434-44.

27. Turner RC, Millns H, Neil HA, Stratton IM, Manley SE, Matthews $D R$, et al. Risk factors for coronary artery disease in non-insulin dependent diabetes mellitus: United Kingdom Prospective Diabetes Study (UKPDS: 23). BMJ. 1998;316(7134):823-8.

28. Benfat R. Studies of a cardiovascular disease and cause-specific mortality trends in Japanese-Americans men living in Hawaii and risk factor comparison with other Japanese populations in the Pacific region: a review. Hum Biol. 1992;64(6):791-805. 